\title{
Ecological Discourse Analysis of an UN Environmental Story in Terms of Transitivity Process
}

Heng Gong, Lingling Liu*

School of Foreign Languages, China Three Gorges University, Daxue Road NO.8, Xiling District, Yichang City, Hubei Province, 443002, PRC.

Corresponding Author: Lingling Liu, E-mail: 283114272@qq.com

\begin{abstract}
ARTICLE INFO
Article history

Received: February 15, 2018

Accepted: April 16, 2018

Published: June 30, 2018

Volume: 9 Issue: 3

Advance access: May 2018

Conflicts of interest:

None Funding: Yes

ABSTRACT

With the rapid development of our economy, the ecology issues are becoming more and more important. In order to raise people's ecological awareness, I conducted this empirical study on the transitivity analysis of a story (Our Way of Life Is Piling Pressure on Ecosystems) from the website of the United Nations Environment Programme. By analysing and comparing the distribution and percentage of different transitivity process in this story, what we can find are:1) the main processes are material process $(60.9 \%)$ and relational process $(21.7 \%)$, followed by the behavioural process $(8.7 \%)$, verbal process $(4.3 \%)$, and existential process $(4.3 \%) ; 2$ ) most of the more-than-human beings influenced by human beings are in the passive position, and few of them are in the positive position; 3 ) no matter what position the more-than-human beings are in, they are always the victims of human beings' activity. Based on the above findings, this story can be regarded as a beneficial discourse, and we should promote and spread it as it can encourage people to protect environment.
\end{abstract}

The research is financed by 1) the Key Research Project of Humanities and Social Science of Hubei Provincial Department of Educa-tion-English Application Research under the Perspective of Functional Linguistics (No. 15D012);2) the Research Fund for Excellent Dissertation of China Three Gorges University (No.2018SSPY157).

\section{Key words:}

Ecolinguistics, Systemic Functional Grammar, Transitivity Analysis, Discourse Analysis, UN Environmental Story

\section{INTRODUCTION}

Nowadays, we are facing with great challenges of environmental problems. Many disciplines are trying to contribute their efforts to this issue. As for linguistics, we can also make our special contribution from the aspect of ecolinguistics through analysing languages. Generally speaking, ecolinguistics research can be done from three perspectives: discourse analysis, applied linguistics, and theoretical linguistics (Huang, 2017:2). Many famous scholars have done their research under the three paradigms, such as Hogben (1972), Halliday (1990), Stibbe (2015), and Huang Guowen (2016). So far, most of studies in China focus on the theory construction and discussion of ecolinguistics, for example, Fan Junjun (2005), and Zhang Ruijie, He Wei (2013), whereas the empirical studies are rare to see, for example, Zhao Ruihua (2016). Hence, my research will try to cover that niche through applying the transitivity analysis from the Systematic Functional Grammar to interpret an ecological discourse form the United Nations Environment Programme (UN Environment). To be specific, this research is going to solve the following research questions:1) What and how many processes is this story made of ? 2) How does each process distribute in this story? By answering this two research questions, this research aims to 1) better understand the UN Environment's standpoint and hidden values by analysing the discourse of the UN Environment; 2) tell what kind of discourse type (beneficial discourse, ambivalent discourse, and destructive discourse) the story is and adopt the proper attitude towards it according to Sttibe's standards (2015); 3) enrich the empirical studies in this field.

\section{DATA COLLECTION}

The discourse I will analyse is an environmental story from the website of United Nations Environment Programme. The title of this story is Our Way of Life Is Piling Pressure on Ecosystems. The first reason why I choose this story is that it is directly related to ecology issue just as its title suggests. The second reason is it has been ranked as one of the top 10 stories of UN Environment of 2017. As we can see, "the UN Environment is the leading global environmental authority that sets the global environmental agenda, promotes the coherent implementation of the environmental dimension of 
sustainable development within the United Nations system, and serves as an authoritative advocate for the global environment" (The United Nations Environment Programme, (n.d.)). With this regard, this story could be highly influential and widely spread. The whole story has 560 words, and I have separated the whole text into 46 clauses in order to do the transitivity analysis.

\section{ANALYTICAL FRAMEWORK}

According to Halliday (1994), language has three metafunctions: ideational, interpersonal, and textual function. Ideational function refers that language can be used to express the experience of the inner and external world, and it includes two categories: experiential and logic function. The experiential function is realized by the transitivity, which consist of six processes and the related participant and circumstance. the six process are material process, relational process, verbal process, behaviour process, mental process and existential process. Material process refers to the process involving physical actions, and it has an actor and a goal; mental process refers to mental process of thinking, imaging, liking, etc., and it has a senser and a phenomenon; relational process is used to describe what kind of relation is between different things, and it has an attribute and a carrier; verbal process is a process of saying, and it has a sayer and a receiver; behaviour process refers to the physiological activities like crying, breathing, listening, etc., and it has a behaver; existential process describes the a process of existing, and it always has an existent and an existential verb. As for the circumstance, it includes time, space, way, content, comparison, identity, etc., and it does not always appear in each process. The transitivity analysis has been widely used by the Critical Discourse Analysis, and it can also be used in the field of ecolinguistics (Stibbe, 2015). The famous ecolinguist Stibbe (2015) put forward that when a discourse encourages us to protect environment, it is a beneficial one, then we should promote it; when part of it encourages us to protect environment, and part of it not, it is an ambivalent one, then we should preserve the good part and resist the bad part; when it encourages us to damage environment, it is a destructive one, then we should resist it.

Hence, I will analyse this story in the following procedure: firstly, I will find out all the processes in this story; secondly, I will count the percentage and the distribution of different process; thirdly, I will compare and analyze different process from the perspective of ecolinguistics; Finally, after the detailed analysis, I will make a judgement of what kind of discourse this story belongs to according to Stibbe's standard.

\section{FINDINGS}

As we can see from the Table 1, the material process takes up $60.9 \%$ of the whole process, followed by the relational process which takes up $21.7 \%$ of the whole process. This two processes all together take up more than $80 \%$ of the entire story, whereas the behavioural process $(8.7 \%)$, verbal process $(4.3 \%)$, existential process $(4.3 \%)$ and mental process $(0 \%)$ only occupy $19.5 \%$ of the whole text. Given that the number and percentage of the behavioural, verbal, and existential process is very limited and they don't show enough meaningful information when compared to other processes, I will not analyse them here. Hence, In the following part, I will focus on analysing the material and relational process one by one to learn how they represent the experiential meaning of the story.

\section{Four Different Groups of the Material Process}

All in all, there are $28(60.9 \%)$ clauses belong to the material process, which is predominant among other processes. After comparing the actors of all the material processes, I find we can divide them into 4 different groups: polluter as the actor, environmental study or organization as the actor, human being as the actor, and creature as the actor. Form Table 2, Table 3, Table 4, and Table 5, we can see that there are 13 material process using different kinds of polluter as their actor, 9 using an environmental study or organization as their actor, 2 using human being as their actor, and 1 use creature as its actor.

In Table 2, we can easily find 9 different polluter produced by human beings' way of life, and what they do the goal is producing pollutant (NO.5,6,7,20,22) or costing damaging to the 'infant' environment (NO.1,2,3,8,12,19,23,25), which can be seen from the fact that the tense of process is present tense or present continuous tense.

Now let's look at the Table 3, which indicates what has been done by an environmental study or organization. On the one hand, they find some polluting is being done (NO.4,11,39), on the other hand, they give a solution to the problem (NO.32, 42,43,44,45,46).

Table 4 gives us a picture of human being from the perspective of asker. As we can see, human beings not only need

Table 1. The distribution of six processes

\begin{tabular}{lccc}
\hline Process & Number & Clause & Percentage \\
\hline Material process & 28 & $1,2,3,4,5,6,7,8,11,12,14,19,20,22,23$, & 60.9 \\
& & $25,26,27,29,32,36,37,39,42,43,44,45,46$ & 21.7 \\
Relational process & 10 & $9,10,21,24,28,30,33,35,38,40$ & 4.3 \\
Verbal process & 2 & 13,34 & 8.7 \\
Behavioural process & 4 & $15,16,17,41$ & 0 \\
Mental process & 0 & & 4.3 \\
Existential process & 2 & 18,31 & 100 \\
Total & 46 & & \\
\hline
\end{tabular}


Table 2. The material processes with Polluter as the actor

\begin{tabular}{|c|c|c|c|}
\hline Actor (Polluter) & Process & Goal & Clause \\
\hline Our way of life & Is piling & Ecosystems & No.1 \\
\hline Carbon dioxide emissions from modern society & Are making & The oceans & No.2 \\
\hline $\begin{array}{l}\text { Climate change, pollution, coastal } \\
\text { development, overfishing and agricultural } \\
\text { fertilizers }\end{array}$ & Is being exacerbated & The situation & No.3 \\
\hline Ocean acidification & Is happening & NULL & No.5 \\
\hline Carbon dioxide from fossil fuels & Dissolves & NULL & No.6 \\
\hline It (carbon dioxide from fossil fuels) & Produces & Carbonic acid & No.7 \\
\hline Which (carbonic acid) & Lowers & The $\mathrm{pH}$ of the water & No.8 \\
\hline (by ocean acidification) & Will be especially harmed & Infant sea creatures & No.12 \\
\hline Which (plastic particles in the oceans) & Cover & 70 per cent of our planet & No.19 \\
\hline Plastic particles in the oceans & Spread & Dangerous pathogens & No.20 \\
\hline Intensive farming & Implies & Excessive use of fertilizer & No.22 \\
\hline Run-off from such farms & Is impairing & $\begin{array}{l}\text { The quality of our lakes and drinking } \\
\text { water sources }\end{array}$ & No.23 \\
\hline \multirow[t]{2}{*}{ All forms of pollution } & Impair or degrade & The ecosystem goods and services & No.25 \\
\hline & & Total & 13 \\
\hline
\end{tabular}

Table 3. The material processes with environmental study/organization as the actor

\begin{tabular}{|c|c|c|c|}
\hline Actor (Environmental study/organization) & Process & Goal & Clause \\
\hline A major new study & Suggests & Carbon dioxide...... agricultural fertilizers & No.4 \\
\hline The eight-year study involving over 250 scientists & Finds & Infant sea creatures will be especially harmed & No.11 \\
\hline $\begin{array}{l}\text { That (consumer, technology and governance } \\
\text { solutions) }\end{array}$ & Can Support & A move & No.32 \\
\hline a 2015 study & Found & $\begin{array}{l}\text { That } 25 \text { per cent of fish sold at markets in } \\
\text { Indonesia and the US had plastic or other } \\
\text { man-made debris in their guts }\end{array}$ & No.39 \\
\hline UN Environment Executive Director Erik Solheim & Published & Towards a Pollution-Free Planet & No.42 \\
\hline Which (towards a pollution-free planet) & Sets Out & A clear framework & No.43 \\
\hline The report & Will Inform & The UN Environment Assembly & No.44 \\
\hline Which (UN Environment Assembly) & Will Gather & & No.45 \\
\hline \multirow[t]{2}{*}{$\begin{array}{l}\text { All governments as well as individuals, businesses } \\
\text { and other organizations }\end{array}$} & $\begin{array}{l}\text { Are Invited } \\
\text { To }\end{array}$ & $\begin{array}{l}\text { Sign the pledge and help \#BeatPollution around } \\
\text { the world }\end{array}$ & No.46 \\
\hline & & Total & 9 \\
\hline
\end{tabular}

Table 4. The material processes with human being as the actor

\begin{tabular}{lllc}
\hline Actor (Human being) & Process & Goal & Clause \\
\hline The world & Will & 40 per cent more water, 50 per cent more food, 40 per cent more energy & No.36 \\
& require & and 40 per cent more timber and fibre & No.37 \\
Nearly 30 per cent of people & Lack & Safe drinking water. & 2 \\
& & Total & \\
\hline
\end{tabular}

water at present (NO.37), but also need more supply in the future (NO.36) to keep living and developing.

Table 6 shows us the fact that the creature-small organisms ingest microplantics in the seawater.

Finally, when we look at Table 2, Table 4 and Table 6 together, we can find no matter what role the 'infant' ecosystem or natural resource or creature plays, they are in a passive situation. They are polluted
(NO.1,2,3,8,12,19,23,25), they are occupied (NO.36, 37), and they eat or bear the harmful pollutant human beings produce (NO.12,14).

\section{Relational Process}

According to Halliday (1994), relational process has two categories: one is attributive relational process, the oth- 
er is identifying relational process. The former refers to what attributive a subject has, for example, a is one of $\mathrm{x}$, and the later means one thing can be identified from another thing, for example, $\mathrm{a}$ is the identity of $\mathrm{x}(\mathrm{Hu}$ Zhuanglin, 2005). Besides, identifying relational process can be reversible whereas attributive one cannot (Halliday, 1994). According to this rule, I find that there are 6 attributive relational processes (Table 6) and 4 identifying ones (Table 7).

In Table 6 , these 6 clauses are used to emphasize the attributive of different entities. Among them, NO.35 shows how our life relies on ecosystem, NO.24 reflects how nutrient load form human activities case damage to lakes, NO.38 is about the polluting, and NO.40 tells us honey is polluted by pesticide. Table 7 shows 4 identifying relational clauses which tell us different fact. NO.21, and NO.28, 30, 33 are about solutions.

\section{DISCUSSION}

From the perspective of ecolinguistics, it is very important for us to discuss what identity the more-than-humans influenced by our way of life have in this story. From my perspective, this story has about 3 more-than-humans: creatures (e.g. fish), ecosystems (e.g. lake) and resources (e.g. water). Hence, based on the findings in the above section, I summarize the role of creatures, ecosystems and resources in this story. As we can see in Table 8, creatures perform the role of actor, goal, behaver and range; ecosystems perform the role of goal, carrier, and attribute; resources perform the role of goal.

Moreover, in Table 9, I further divided them into two groups: passive group and positive group. First of all, it is interesting to see that most of them are in the passive group in which they are in a less powerful position and being dominated by others. For creatures, they are studied, eat-

Table 5. Attributive relational processes

\begin{tabular}{lllc}
\hline Carrier & Process & Attribute & Clause \\
\hline The assessment & Comes from & The bioacid project & No.9 \\
Which & Is led from & Germany & No.10 \\
$\begin{array}{l}\text { In extreme cases the nutrient load from such activities } \\
\text { (mainly in the form of nitrates and phosphorus) }\end{array}$ & Leads to & Algal blooms on & No.24 \\
"ultimately, human health and well-being & & lakes & The very ecosystems \\
55 per cent of us rivers and streams & Depend on & In poor condition. & No.35 \\
75 per cent of honey & Are & Traces of pesticide & No.40 \\
& Contains & Total & 6 \\
\hline
\end{tabular}

Table 6. The material process with creature as the actor

\begin{tabular}{lllc}
\hline Actor (Creature ) & Process & Goal & Clause \\
\hline by small organisms & Are being ingested & Microplastics in seawater & No.14 \\
& & Total & 1 \\
\hline
\end{tabular}

Table 7. Identifying relational processes

\begin{tabular}{llll}
\hline Identified & Process & Identifier & Clause \\
\hline $\begin{array}{l}\text { On land, toxic chemical waste from factories, sewage from cities, } \\
\text { noxious fumes from transport systems, plastic pollution in our cities, } \\
\text { and human-induced peatland fires }\end{array}$ & Are & Just some of the things & No.21 \\
$\begin{array}{l}\text { The trick } \\
\text { The good news }\end{array}$ & Is & $\begin{array}{l}\text { To adopt a middle road. } \\
\text { Is }\end{array}$ & $\begin{array}{l}\text { That consumer, technology and } \\
\text { governance solutions exist towards } \\
\text { sustainable practices. }\end{array}$ \\
Un environment's role in this & Is & $\begin{array}{l}\text { To help } \\
\text { Total }\end{array}$ & No.33 \\
& & &
\end{tabular}

Table 8. The Role of Creatures, Ecosystems and Resources

\begin{tabular}{lcccccc}
\hline & Actor & Goal & Carrier & Attribute & Behaver & Range (goal) \\
\hline Creatures & NO.14 & NO.11,12 & & & NO.15 & No.16,17 \\
Ecosystems & & NO.1,2,19,23 & NO.38 & NO.24,35 & & \\
Resources & & NO.8,25,36,37 & & & & \\
\hline
\end{tabular}


Table 9: The passive group and positive group of creatures, ecosystems and resources

\begin{tabular}{lll}
\hline Passive & No.11,12 & Being studied and harmed by human beings \\
Creatures & No.16 & Being eaten by human beings \\
Ecosystems & No.17 & Being eaten by the same kind \\
Resources & No.1,2,19,23,24 & Being harmed by human beings \\
Positive & No.35 & Being depended on by human beings \\
Creatures & No.8,25 & Being harmed by human beings \\
Ecosystems & No.36,37 & Being occupied by human beings \\
& No.14,15 & Eating harmful substance \\
\hline
\end{tabular}

en, and harmed by human beings (NO.11,12,16), and in the bottom of the food chain (NO.17). For ecosystems, one the one hand, they are relied by human beings as they provide necessary elements (NO.1,2,19,23,24), whereas on the other hand, they are harmed-polluted by human beings' activity(NO.35). The same thing also happens to the resources (NO.8,25,36,37). Secondly, very few of them are in the positive group in which they are doing something out of their own will, and they are still influenced by human beings. Creatures eat food out of their biological habits; however, what they eat is harmful substance like plastic particles. Ecosystems exist and running every day, but what they are carrying is a bad attribute, for example, the ocean is acidic. So through transitivity analysis, we now have a detailed and concrete understanding of how the piling is actually happening, and it is also easy to find that no matter what position the more-than-human beings are in, they are always the victims.

Besides, Stibbe (2015) discussed the link between language and ecology that our language shaped our ideologies, worldviews and other things controlling our behaviour towards each other and the environment. Hence, we can start with the languages we live by to protect the ecosystems we live by.

We all know that English, now as the most powerful language and the lingua franca of the $21^{\text {st }}$ century, has huge influence on nearly all aspects of our life. Many important environment documents are exposed mostly in English, like the Kyoto Protoco (1997), the United Nations Framework Convention on Climate Change (1992) and the Paris Agreement (2015); many famous ecological literature works like The Silent Spring, one of the most influential ecological works, was written in English. In addition to English, there are many other influential languages all over the world. For example, Chinese, the mother tongue of more than 1.3 billion people. Just like China, as the biggest developing country, can play an important role in global environment issues, Chinese, as the most used language, can also contribute a lot to the ecological problems. Chinese government has put forward the eco-civilization construction framework since 2007, by which a lot of ecological discourses have been widely spread. Most of them are at least ambivalent ones, for example, the most popular slogan put forward by president XI Jinping (2017): “我们既要绿水青山, 也要 金山银山。宁要绿水青山, 不要金山银山, 而且绿水 青山就是金山银山” (clean waters and green mountains are invaluable assets and we need all of them, but we should give priority to the formers). If we look at it from the perspective of deep ecology, this slogan can be regarded as an ambivalent discourse, as on the one hand, it emphasizes the protection of environment, and on the other hand, it regards natural world as assets to be used. However, if we look at it from the perspective of shallow ecology, it is a beneficial one, because it encourages us to keep a balance between economic development and environment protection, which is more practical for China's and other developing countries' current situation. All in all, if we can make best use of our languages by promoting beneficial ones, change ambivalent ones, and resist destructive ones, we can make a great difference in protecting our earth -- the only homeland we have so far.

\section{CONCLUSION}

To sum up, more than $80 \%$ of the entire story is made up of the material process $(60.9 \%)$ and relational process $(21.7 \%)$, whereas the behavioural process $(8.7 \%)$, verbal process $(4.3 \%)$, existential process $(4.3 \%)$ and mental process $(0 \%)$ only occupy $19.5 \%$ of the whole text. As we know, material process refers to the process of doing something (Halliday, 1994). Through constructing different role of human beings and more-than-human beings in these material processes, the author tells us a vivid yet sad story about how our way of life is piling pressure on ecosystems: most of the more-than-human beings influenced by human beings are in the passive position, and only few of them are in the positive position; no matter what position the morethan-human beings are in, they are always the victims of human beings' activity. Most importantly, this story told by the leading global environmental authority, according to the theory of Stibbe (2015), is a beneficial discourse worthy of promoting and spread as it encourages us to protect our ecosystem. We need more stories from different languages like this one to raise people's awareness of ecology, because through uncovering the hidden ideology by analysing ecological discourses, we can evoke people's ecological awareness, then to encourage them to behave more environment-friendly. Last but not least, this research has enriched and shed some light on the empirical studies in the domain of ecological discourse analysis by applying transitivity process analysis. 


\section{END NOTES}

1. The website of this story: https://www.unenvironment. org/news-and-stories/story/our-way-life-piling-pressure-ecosystems

2. UN Environment: United Nations Environment Programme

\section{REFERENCES}

Haugen, E. (1972). The ecology of language. Palo Alto: Stanford University Press.

Halliday, M.A.K. (1994a). New ways of meaning: the challenge to applied linguistics. London. Journal of Applied Linguistics. 10(6),7-36.

Halliday, M.A.K. (1994b). An introduction to functional grammar. London: Edward Arnold.

Stabbed, A.(2015). Ecolinguistics-language, ecology and the stories we live by. London: Routledge.

The United Nations Environment Programme. (2017). About UN Environment. Retrived from https://www.unenvironment.org/about-un-environment. Accessed 3 Jan 2018.

Fan, J.J. (2005). 生态语言学研究述评 [review of ecolinguistics research]. Foreign Language Teaching and Research. (02):110-115
He, W. and Zhang, R.J. (2017). 生态话语分析模式构/an ecological analytical framework for discourse]. Foreign Languages in China. 14(05):56-64.

Huang, G.W. (2016). 外语教学与研究的生态化取向 [ecological orientation on foreign language teaching and research] Foreign Languages in China. 13(05), 9-13.

Huang, G.W. (2017). 从系统功能语言学到生态语言学 [from systemic functional linguistics to ecolinguistics]. Foreign Language Education. 38(05), 1-7.

Hu, Z.L., Zhu, Y.S., Zhang, D.L., \& Li, Z.Z. (2005). 系统功 能语言学概论 [introduction to systemic functional linguistics]. Beijing: Peking University Press.

Literature Research Office of the CPC Central Committee. (2017). 习近平关于社会主义生态文明建设论述摘 编 [Xi Jinping thought on socialism ecological civilization]. Beijing: Central Party Literature Press.

Zhao, R. H. (2016). 系统功能视角下生态话语分析的多 层面模式一一以生态报告中银无须鳕身份构建为例 [a multi-stratal pattern of ecological discourse analysis from a systemic functional perspective: a case study on the identity construction of silver hake in ecological assessment reports]. Foreign Languages in China. 13(05): 84-91.

\section{APPENDIX}

\section{Appendix: Availability of data and material}

\section{Data: The English Text}

https://www.unenvironment.org/news-and-stories/story/our-way-life-piling-pressure-ecosystems

Our way of life is piling pressure on ecosystems

Carbon dioxide emissions from modern society are making the oceans more acidic, and the situation is being exacerbated by climate change, pollution, coastal development, overfishing and agricultural fertilizers, a major new study suggests.

Ocean acidification is happening because as carbon dioxide from fossil fuels dissolves in seawater, it produces carbonic acid, which lowers the $\mathrm{pH}$ of the water.

The assessment comes from the BIOACID project, which is led from Germany. The eight-year study involving over 250 scientists finds infant sea creatures will be especially harmed, the BBC reports.

Meanwhile, microplastics in seawater are being ingested by small organisms. Small fish are eating these organisms, and we are eating the bigger fish that eat them. There is even evidence that plastic particles in the oceans, which cover 70 per cent of our planet, can spread dangerous pathogens.

On land, toxic chemical waste from factories, sewage from cities, noxious fumes from transport systems, plastic pollution in our cities, and human-induced peatland fires are just some of the things degrading the ecological foundation of sustainable development.

Intensive farming implies excessive use of fertilizer to maximize crop yields and profits, but at what cost? Run-off from such farms is impairing the quality of our lakes and drinking water sources. In extreme cases the nutrient load from such activities (mainly in the form of nitrates and phosphorus) leads to algal blooms on lakes, rendering them useless, even hazardous.

All forms of pollution impair or degrade the ecosystem goods and services we take for granted - like clean air, freshwater, wood, or the health and recreational benefits afforded by the great outdoors.

With a rapidly growing population, the world will need more energy, more water and more food in the future, placing an even greater burden on already fragile ecosystems. The trick is to adopt a middle road that delivers results for biodiversity, energy, food and jobs. The good news is that consumer, technology and governance solutions exist that can support a move towards sustainable practices.

"UN Environment's role in this is to help highlight the problems and broker practical, cost-effective, science-based solutions," says UN Environment ecosystems expert Niklas Hagelberg. "Ultimately, human health and well-being depend on the very ecosystems which nurture us and of which we are a part."

\section{Vital statistics}

- $\quad$ By 2030, the world will require 40 per cent more water, 50 per cent more food, 40 per cent more energy and 40 per cent more timber and fibre. 
- $\quad$ Nearly 30 per cent of people still lack safe drinking water.

- 55 per cent of US rivers and streams are in poor condition.

- A 2015 study found that 25 per cent of fish sold at markets in Indonesia and the US had plastic or other man-made debris in their guts.

- 75 per cent of honey contains traces of pesticide.

- A 75 per cent decline in flying insects in German protected areas has been observed over the last 27 years.

Last month, UN Environment Executive Director Erik Solheim published Towards a Pollution-Free Planet, which sets out a clear framework for action on pollution. The report will inform the UN Environment Assembly, which will gather from 4-6 December in Nairobi, Kenya, under the theme of pollution. All governments as well as individuals, businesses and other organizations are invited to sign the pledge and help \#BeatPollution around the world.

\section{Details of analysis: original tables, lists, etc.}

Our way of life is piling pressure on ecosystems

1. Our way of life is piling pressure on ecosystems

Material process

2. Carbon dioxide emissions from modern society are making the oceans more acidic,

Material process

3. And the situation is being exacerbated by climate change, pollution, coastal development, overfishing and agricultural fertilizers, Material process

4. a major new study suggests.

Material process

5. Ocean acidification is happening because

Material process

6. as carbon dioxide from fossil fuels dissolves in seawater,

Material process

7. it produces carbonic acid,

Material process

8. which lowers the $\mathrm{pH}$ of the water.

Material process

9. The assessment comes from the BIOACID project,

Relational process

10. which is led from Germany.

Relational process

11. The eight-year study involving over 250 scientists finds infant sea creatures will be especially harmed,

Material process

12. infant sea creatures will be especially harmed,

Material process

13. the BBC reports.

Verbal process

14. Meanwhile, microplastics in seawater are being ingested by small organisms.

Material process

15. Small fish are eating these organisms,

Behavioral process/material process

16. and we are eating the bigger fish

Behavioral process/material process

17. the bigger fish that eat them.

Behavioral process/material process

18. There is even evidence that plastic particles in the oceans,

Existential process

19. which cover 70 per cent of our planet,

Material process

20. can spread dangerous pathogens.

Material process

21. On land, toxic chemical waste from factories, sewage from cities, noxious fumes from transport systems, plastic pollution in our cities, and human-induced peatland fires are just some of the things degrading the ecological foundation of sustainable development.

Relational process

22. Intensive farming implies excessive use of fertilizer to maximize crop yields and profits, but at what cost?

Material process 
23. Run-off from such farms is impairing the quality of our lakes and drinking water sources.

Material process

24. In extreme cases the nutrient load from such activities (mainly in the form of nitrates and phosphorus) leads to algal blooms on lakes, rendering them useless, even hazardous.

Relational process

25. All forms of pollution impair or degrade the ecosystem goods and services we take for granted - like clean air, freshwater, wood, or the health and recreational benefits afforded by the great outdoors.

Material process

26. With a rapidly growing population, the world will need more energy, more water and more food in the future, placing an even greater burden on already fragile ecosystems.

Material process

27. (the world will need more energy, more water and more food in the future)placing an even greater burden on already fragile ecosystems.

Material process

28. The trick is to adopt a middle road that delivers results for biodiversity, energy, food and jobs.

Relational process

29. a middle road that delivers results for biodiversity, energy, food and jobs.

Material process

30. The good news is that consumer, technology and governance solutions exist that can support a move towards sustainable practices.

Relational process

31. consumer, technology and governance solutions exist

Existential process

32. that can support a move towards sustainable practices.

Material process

33. "UN Environment's role in this is to help highlight the problems and broker practical, cost-effective, science-based solutions," relational process

34. "UN Environment's role in this is to help highlight the problems and broker practical, cost-effective, science-based solutions," says UN Environment ecosystems expert Niklas Hagelberg.

Verbal process

35. "Ultimately, human health and well-being depend on the very ecosystems which nurture us and of which we are a part." Relational process

Vital statistics

36. By 2030, the world will require 40 per cent more water, 50 per cent more food, 40 per cent more energy and 40 per cent more timber and fibre.

Material process

37. Nearly 30 per cent of people still lack safe drinking water.

Material process

38. 55 per cent of US rivers and streams are in poor condition.

Relational process

39. A 2015 study found that 25 per cent of fish sold at markets in Indonesia and the US had plastic or other man-made debris in their guts.

Material process

40. 75 per cent of honey contains traces of pesticide.

Relational process

41. A 75 per cent decline in flying insects in German protected areas has been observed over the last 27 years.

Behavioral process

42. Last month, UN Environment Executive Director Erik Solheim published Towards a Pollution-Free Planet,

Material process

43. Which sets out a clear framework for action on pollution

Material process

44. The report will inform the UN Environment Assembly,

Material process

45. Which will gather from 4-6 December in Nairobi, Kenya, under the theme of pollution.

Material process

46. All governments as well as individuals, businesses and other organizations are invited to sign the pledge and help \#BeatPollution around the world.

Material process 


\begin{tabular}{lcc}
\hline Process & Number & Percentage \\
\hline Material process & 28 & 60.9 \\
Relational process & 10 & 21.7 \\
Verbal process & 2 & 4.3 \\
Behavioral process & 4 & 8.7 \\
Mental process & 0 & 0 \\
Existential process & 2 & 4.3 \\
Total & 46 & 100 \\
\hline
\end{tabular}

\begin{tabular}{|c|c|c|c|}
\hline ACTOR & PROCESS & GOAL & PLACE \\
\hline \multicolumn{4}{|l|}{ Polluter } \\
\hline Our way of life & Is piling & Ecosystems & 1 \\
\hline Carbon dioxide emissions from modern society & Are making & The oceans & 2 \\
\hline $\begin{array}{l}\text { Climate change, pollution, coastal } \\
\text { development,overfishing and agricultural fertilizers }\end{array}$ & Is being exacerbated & The situation & 3 \\
\hline Ocean acidification & Is happening & & 5 \\
\hline Carbon dioxide from fossil fuels & Dissolves & & 6 \\
\hline It (carbon dioxide from fossil fuels) & Produces & Carbonic acid & 7 \\
\hline Which (carbonic acid) & Lowers & The $\mathrm{pH}$ of the water & 8 \\
\hline (by ocean acidification) & $\begin{array}{l}\text { Will be especially } \\
\text { harmed }\end{array}$ & Infant sea creatures & 12 \\
\hline Which (plastic particles in the oceans) & Cover & 70 per cent of our planet & 19 \\
\hline Plastic particles in the oceans & Spread & Dangerous pathogens & 20 \\
\hline Intensive farming & Implies & Excessive use of fertilizer & 22 \\
\hline Run-off from such farms & Iis impairing & $\begin{array}{l}\text { The quality of our lakes and } \\
\text { Drinking water sources }\end{array}$ & 23 \\
\hline All forms of pollution & Impair or degrade & The ecosystem goods and services & 25 \\
\hline \multicolumn{4}{|l|}{ Study/Research } \\
\hline A major new study & Suggests & & 4 \\
\hline The eight-year study involving over 250 scientists & finds & $\begin{array}{l}\text { Infant sea creatures will be } \\
\text { especially harmed }\end{array}$ & 11 \\
\hline $\begin{array}{l}\text { That (consumer, technology and governance } \\
\text { solutions) }\end{array}$ & Can support & A move & 32 \\
\hline a 2015 study & Found & $\begin{array}{l}\text { That } 25 \text { per cent of fish sold at } \\
\text { markets in Indonesia and the US } \\
\text { had plastic or other man-made } \\
\text { debris in their guts }\end{array}$ & 39 \\
\hline Which (towards a pollution-free planet) & Sets out & A clear framework & 43 \\
\hline The report & Will inform & The UN Environment Assembly & 44 \\
\hline \multicolumn{4}{|l|}{ Individual/Organization/Institution } \\
\hline UN Environment Executive Director Erik Solheim & Published & Towards a Pollution-Free Planet & 42 \\
\hline Which (UN Environment Assembly) & Will gather & & 45 \\
\hline $\begin{array}{l}\text { All governments as well as individuals, businesses } \\
\text { and other organizations }\end{array}$ & Are invited to & & 46 \\
\hline \multicolumn{4}{|l|}{ Human being } \\
\hline The world & Will require & $\begin{array}{l}40 \text { per cent more water, } 50 \text { per } \\
\text { cent more food, } 40 \text { per cent more } \\
\text { energy and } 40 \text { per cent more timber } \\
\text { and fibre }\end{array}$ & 36 \\
\hline Nearly 30 per cent of people & Lack & Safe drinking water. & 37 \\
\hline \multicolumn{4}{|l|}{ Creature } \\
\hline By small organisms & Are being ingested & Microplastics in seawater & 14 \\
\hline
\end{tabular}




\begin{tabular}{|c|c|c|c|}
\hline ACTOR (Polluter) & PROCESS & GOAL & CLAUSE \\
\hline Our way of life & Is piling & Ecosystems & No.1 \\
\hline $\begin{array}{l}\text { Carbon dioxide emissions from modern } \\
\text { society }\end{array}$ & Are making & The oceans & No. 2 \\
\hline $\begin{array}{l}\text { Climate change, pollution, coastal } \\
\text { development, Overfishing and agricultural } \\
\text { fertilizers }\end{array}$ & Is being exacerbated & The situation & No.3 \\
\hline Ocean acidification & \multicolumn{2}{|l|}{ Is happening } & No.5 \\
\hline Carbon dioxide from fossil fuels & \multicolumn{2}{|l|}{ Dissolves } & No.6 \\
\hline It (carbon dioxide from fossil fuels) & Produces & Carbonic acid & No.7 \\
\hline Which (carbonic acid) & Lowers & The $\mathrm{pH}$ of the water & No. 8 \\
\hline (by ocean acidification) & $\begin{array}{l}\text { Will be especially } \\
\text { harmed }\end{array}$ & Infant sea creatures & No.12 \\
\hline Which (plastic particles in the oceans) & Cover & 70 per cent of our planet & No.19 \\
\hline Plastic particles in the oceans & Spread & Dangerous pathogens & No.20 \\
\hline Intensive farming & Implies & Excessive use of fertilizer & No.22 \\
\hline Run-off from such farms & Is impairing & $\begin{array}{l}\text { The quality of our lakes and drinking water } \\
\text { sources }\end{array}$ & No.23 \\
\hline All forms of pollution & Iimpair or degrade & The ecosystem goods and services & No.25 \\
\hline Actor (Study/research) & Process & Goal & Clause \\
\hline A major new study & Suggests & \multirow[b]{2}{*}{ Infant sea creatures will be especially harmed } & No.4 \\
\hline The eight-year study involving over 250 scientists & Finds & & No.11 \\
\hline $\begin{array}{l}\text { That (consumer, technology and governance } \\
\text { solutions) }\end{array}$ & Can support & A move & No.32 \\
\hline A 2015 study & Found & $\begin{array}{l}\text { That } 25 \text { per cent of fish sold at markets in } \\
\text { Indonesia and the US had plastic or other } \\
\text { man-made debris in their guts }\end{array}$ & No.39 \\
\hline Which (towards a pollution-free planet) & Sets out & A clear framework & No.43 \\
\hline The report & Will inform & The UN Environment Assembly & No.44 \\
\hline \multicolumn{2}{|l|}{ Actor (Individual/organization/institution) } & Process & Clause \\
\hline UN environment executive director erik solheim & $\mathrm{Pul}$ & Towards a pollution-free planet & No.42 \\
\hline Which (UN environment assembly) & Wi & 11 gather & No.45 \\
\hline $\begin{array}{l}\text { All governments as well as individuals, businesses } \\
\text { organizations }\end{array}$ & es and other & e invited to & No.46 \\
\hline
\end{tabular}

\begin{tabular}{|c|c|c|c|}
\hline Actor (Human being) & Process & Goal & Clause \\
\hline The world & Will require & $\begin{array}{l}40 \text { per cent more water, } 50 \text { per cent } \\
\text { more food, } 40 \text { per cent more energy } \\
\text { and } 40 \text { per cent more timber and fibre }\end{array}$ & NO.36 \\
\hline Nearly 30 per cent of people & Lack & Safe drinking water. & NO.37 \\
\hline Actor (Creature) & Process & Goal & Clause \\
\hline By small organisms & Are being ingested & Microplastics in seawater & No.14 \\
\hline
\end{tabular}




\begin{tabular}{|c|c|c|c|c|}
\hline \multicolumn{2}{|l|}{ Carrier } & Process & Attribute & Clause \\
\hline \multicolumn{2}{|l|}{ The assessment } & $\begin{array}{l}\text { Comes } \\
\text { from }\end{array}$ & The bioacid project & No.9 \\
\hline \multicolumn{2}{|l|}{ Which } & Is led from & Germany & No.10 \\
\hline \multicolumn{2}{|c|}{$\begin{array}{l}\text { On land, toxic chemical waste from factories, } \\
\text { sewage from cities, noxious fumes from } \\
\text { transport systems, plastic pollution in our cities, } \\
\text { and human-induced peatland fires }\end{array}$} & Are & $\begin{array}{l}\text { Just some of the things degrading the ecological } \\
\text { foundation of sustainable development. }\end{array}$ & No.21 \\
\hline \multicolumn{2}{|c|}{$\begin{array}{l}\text { In extreme cases the nutrient load from such } \\
\text { activities (mainly in the form of nitrates and } \\
\text { phosphorus) }\end{array}$} & Leads to & $\begin{array}{l}\text { Algal blooms on lakes, rendering them useless, even } \\
\text { hazardous. }\end{array}$ & No. 24 \\
\hline \multicolumn{2}{|l|}{ The trick } & Is & $\begin{array}{l}\text { To adopt a middle road that delivers results for } \\
\text { biodiversity, energy, food and jobs. }\end{array}$ & No. 28 \\
\hline \multicolumn{2}{|l|}{ The good news } & Is & $\begin{array}{l}\text { That consumer, technology and governance solutions } \\
\text { exist that can support a move towards sustainable } \\
\text { practices. }\end{array}$ & No.30 \\
\hline \multicolumn{2}{|c|}{ 'Un environment's role in this } & Is & $\begin{array}{l}\text { To help highlight the problems and broker practical, } \\
\text { cost-effective, science-based solutions," says un } \\
\text { environment ecosystems expert Niklas Hagelberg. }\end{array}$ & No.33 \\
\hline \multicolumn{2}{|c|}{ "Ultimately, human health and well-being } & Depend on & $\begin{array}{l}\text { The very ecosystems which nurture us and of which } \\
\text { we are a part." }\end{array}$ & No.35 \\
\hline \multicolumn{2}{|c|}{55 per cent of us rivers and streams } & Are & In poor condition. & No.38 \\
\hline \multicolumn{2}{|l|}{75 per cent of honey } & Contains & Traces of pesticide & No.40 \\
\hline Behaver & Process & \multicolumn{2}{|l|}{ Range } & Clause \\
\hline Small fish & Are eating & \multicolumn{2}{|l|}{ These organisms, } & No.15 \\
\hline And we & Are eating & \multicolumn{2}{|c|}{ The bigger fish that eat them. } & No.16 \\
\hline \multirow[t]{2}{*}{ (the bigger fish) that } & Eat & \multicolumn{2}{|l|}{ Them } & No.17 \\
\hline & Has been observed & \multicolumn{2}{|c|}{$\begin{array}{l}\text { A } 75 \text { per cent decline in flying insects in German protected areas over the } \\
\text { last } 27 \text { years. }\end{array}$} & No.41 \\
\hline
\end{tabular}

